\title{
Long coronary artery aneurysm treated by two graft stents on a single bare metal stent scaffold
}

Długi tętniak tętnicy wieńcowej leczony implantacją dwóch stentgraftów na szkielecie z pojedynczego stentu metalowego

\author{
Hekim Karapinar', Zekeriya Kucukdurmaz', Hasan Ali Gümrükçüoğlu², Ahmet Yılmaz' \\ 1Department of Cardiology, Cumhuriyet University Faculty of Medicine, Sivas, Turkey \\ 2Department of Cardiology, Van High Specialty Education and Research Hospital, Van, Turkey
}

Postep Kardiol Inter 2012; 8, 2 (28): 179-180

DOI: $10.5114 /$ pwki.2012.29662

\begin{abstract}
We report a case of a 61-year-old male who presented with symptoms of stable angina. The coronary angiography revealed a long aneurysm and significant stenosis after the aneurysmatic segment on the circumflex artery. The length of the aneurysm was $21 \mathrm{~mm}$ with the largest diameter $9 \mathrm{~mm}$. We thought that single graft stent placement was not possible due to the angled circumflex artery, length of the aneurysm and inflexible nature of graft stents. Distal stenosis was stented as usual. A bare metal stent was implanted over the aneurysm from normal to normal segments. Two graft stents were implanted sequentially in the aneurysm over the bare metal stent scaffold. Stent grafts covered the aneurysm without any main side branch occlusion. The patient was discharged the next day without any complications. The patient was asymptomatic after two years of follow-up with usual medications.
\end{abstract}

Key words: coronary artery aneurysm, percutaneous coronary intervention, stent graft

\section{Streszczenie}

Przedstawiamy przypadek 61-letniego mężczyzny, który zgłosił się z powodu objawów stabilnej choroby wieńcowej. W koronarografii wykazano obecność długiego tętniaka gałęzi okalającej zwężonej istotnie za tętniakowato poszerzonym odcinkiem. Długość tętniaka wynosiła $21 \mathrm{~mm}$, a jego największa średnica $9 \mathrm{~mm}$. Uznano, że wszczepienie pojedynczego stentgraftu jest niemożliwe ze względu na krzywiznę gałęzi okalającej, długość tętniaka i sztywny charakter stentgraftu. Zwężenie w odcinku dystalnym zaopatrzono typową implantacją stentu. Przez całą długość tętniaka implantowano stent metalowy, którego granice znajdowały się w obrębie prawidłowych odcinków tętnicy. Następnie w obrębie stentu metalowego wszczepiono kolejno dwa stentgrafty, które w całości pokryły tętniaka, nie powodując jednocześnie zamknięcia żadnej z głównych bocznic. Pacjent został wypisany następnego dnia bez powikłań i nie zgłaszał objawów w ciągu 2 lat obserwacji, stosując typowe leczenie farmakologiczne.

Słowa kluczowe: tętniak tętnicy wieńcowej, przezskórna interwencja wieńcowa, stentgraft

Dear editor,

We have read the recent case report by Król et al. [1] with great interest. The authors reported a case with giant aneurysm in the left anterior descending artery which was treated with two stent grafts on a bare metal stent scaffold.

We have also reported a 61-year-old male who suffered from stable angina pectoris. He had no history of coronary artery disease but he was diabetic for 5 years, hypertensive for 15 years and on statin treatment for hypercholesterolemia and he had never smoked. He had no family history for coronary artery disease. Coronary angiography revealed a giant aneurysm on the mid portion and a significant stenosis on the distal portion of the circumflex artery (Cx) (Figure 1). The right coronary artery was non-dominant and had a 50\% stenosis on the mid portion. The first diagonal branch of the left anterior descending artery was diffusely atherosclerotic and the first obtuse marginal branch of the circumflex artery was occluded but both vessels were diminutive in diameter.

Corresponding author/Adres do korespondencji:

Hekim Karapinar MD, Assist. Prof., Cumhuriyet Universitesi, Araștırma ve Uygulama Hastanesi Kardiyoloji Anabilim Dall, 58140 Sivas, Turkey, tel.: +90 505 3149560, fax: +90 346 2191155, e-mail: drhekim@yahoo.com

Praca wptynęła: 10.02.2012, przyjęta do druku: 11.04.2012. 


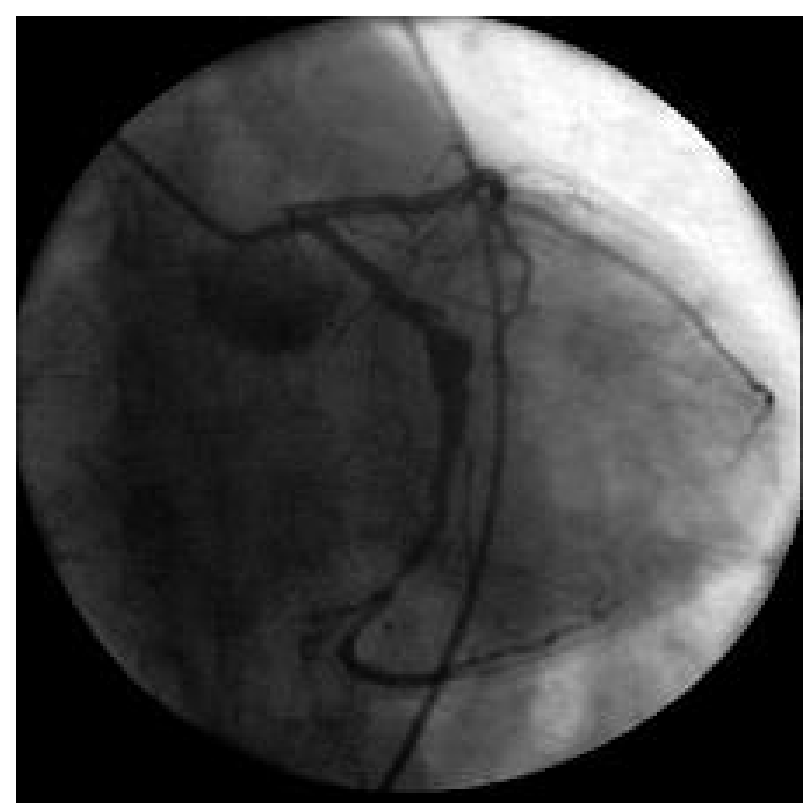

Fig. 1. Aneurysm is seen in mid portion of circumflex artery

Ryc. 1. Tętniak w środkowym odcinku gatęzi okalającej

Angioplasty was planned for stenosis and aneurysm on the Cx. But the aneurysmatic segment was unreachable for the single graft stent placement because of the angled nature of the $\mathrm{Cx}$ and the limited flexibility of graft stents associated with their double-layered strut profile. The strategy was planned as deployment of two graft stents over a single longer bare metal stent (BMS) as a scaffold. A $2.75 \mathrm{~mm} \times 9 \mathrm{~mm}$ BMS (Ephesos II stent system, Alvimedica, Turkey) was deployed at $8 \mathrm{~atm}$ to the distal CX lesion, successfully. Then a $3.0 \mathrm{~mm} \times 25 \mathrm{~mm}$ BMS (Ephesos II stent system, Alvimedica, Turkey) was deployed onto the aneurysm at $12 \mathrm{~atm}$ by covering the proximal and distal healthy segments. Subsequently a $3.0 \mathrm{~mm} \times 16 \mathrm{~mm}$ graft stent (Jostent Graftmaster, Abbot vascular, US) was deployed at $15 \mathrm{~atm}$ onto the proximal part of the BMS and then a $3.0 \mathrm{~mm} \times 12 \mathrm{~mm}$ graft stent (Jostent Graftmaster, Abbot vascular, US) was deployed at $15 \mathrm{~atm}$ onto the distal part of the BMS, and the overlap segment of the stents was post-dilated by a $3.0 \mathrm{~mm} \times 12 \mathrm{~mm}$ non-compliant balloon (Quantum Maverick Balloon, Boston Scientific, US) at $20 \mathrm{~atm}$. Angiography revealed complete covering of the aneurysmatic segment without loss of main side branches (Figure 2). The patient was discharged the next day with optimized medical treatment. At $1^{\text {st }}$ month, $6^{\text {th }}$ month, $1^{\text {st }}$ year and $2^{\text {nd }}$ year follow-ups the patient was on medication and asymptomatic.

Both reports emphasized the innovative treatment of long coronary aneurysms by multiple graft stents on a bare metal stent scaffold. This technique might be useful in coronary aneurysms longer than commercially available graft stent sizes and in aneurysms which are unreachable

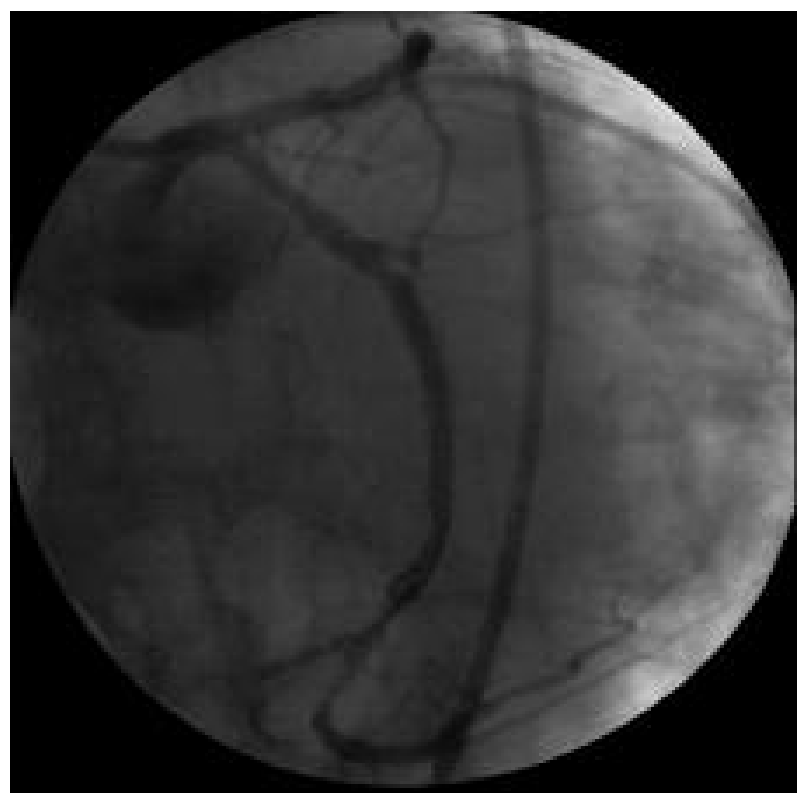

Fig. 2. Circumflex artery is seen after implantation of two stent grafts on long bare metal stent scaffold Ryc. 2. Gałąź okalająca po implantacji dwóch stentgraftów na długim szkielecie ze stentu metalowego

due to the inflexibility of the graft stent and angled nature of the coronary artery.

\section{Acknowledgments}

The authors have no conflict of interest or financial support for this work.

\section{References}

1. Król M, Skwarna B, Gałuszka G, et al. Giant aneurysm in medial anterior descending artery: treatment with two endovascular stent grafts on bare metal stent scaffold. Postep Kardiol Inter 2011; 7: 173-177. 